\title{
On multi-strain model for Hepatitis C
}

\author{
E Ahmed $^{1 *}$ and HA El-Saka ${ }^{2}$
}

\begin{abstract}
In this paper we present a multi-strain model for hepatitis $\mathrm{C}$ virus (HCV) including an immune response term. The model is presented and discussed. Also we argue that the added multi-strain term represents some basic

properties of the immune system and that it should be included to study longer term behavior of the disease.
\end{abstract}

\section{Introduction}

Hepatitis $C$ is one of many serious infectious diseases affecting humans. An estimated about 170 million people worldwide are infected with hepatitis $C$. No vaccine against hepatitis $\mathrm{C}$ is available. Egypt has the highest rate of infections by hepatitis $\mathrm{C}$ virus (HCV) genotype 4 . Chronic HCV infection is the main cause leading to liver transplant or death [1]. Antiviral therapy has been used to treat chronically HCV infected patients. Relatively successful treatment contains pegylated interferon (PEG-IFN) and ribavirin (RBV). Typical response ate biphasic beginning with rapid viral decline phase followed by slower decline phase. Sometimes there is more complicated behavior but they will not be discussed here. Extensive and impressive studies have been done by Perelson and his group [4-6]. Here we present a multi-strain generalization of a basic HCV model [4] including the immune response (Ir) term proposed in [3].

Why do we need mathematical models for HCV?

i) The ideal research group should contain both medical doctors (MD) and mathematicians/and or biophysicists c.f. Perelson group (Santa Fe).

ii) A standard result is that multi-drugs have to be used for treatment. This does not seem to be the case for hepatitis C. Only Peg-IFN is used. Ribavirin (RBV) cannot be considered as independent drug since, if used independently, it has no effect on HCV.

iii) Multi-strain effects are relevant to HCV. Mathematical models for multi-strain viruses can be quite useful. In fact trying to anticipate the new strains experimentally is quite difficult [7].

\footnotetext{
* Correspondence: magd45@yahoo.com

${ }^{1}$ Mathematics Department, Faculty of Science, Mansoura University, 35516, Mansoura, Egypt

Full list of author information is available at the end of the article
}

iv) Spatial effects of epidemics can be important. Typically they are difficult to quantify. Mathematical models can help in this problem.

In sec.2 the model is presented and discussed. Also we argue that the added immune response term represents some basic properties of the immune system and that it should be included to study longer term behavior of the disease.

\section{The model and conclusions}

The fractional order hepatitis $\mathrm{C}$ virus (HCV) model is given by

$$
\begin{aligned}
& D^{\alpha} T=s-d T-(1-\eta) \beta V T, \\
& D^{\alpha} I=(1-\eta) \beta V T-\delta I\left(1-I / c_{2}\right), \\
& D^{\alpha} V=\left(1-\varepsilon_{p}\right) p I-c V,
\end{aligned}
$$

Where $0<\alpha \leq 1, T$ represents uninfected hepatocytes, $I$ represents infected hepatocytes and $V$ represents virus. The model assumes that uninfected hepatocytes are produced at a constant rate $s$, die at rate, $d$, per cell and are infected at constant rate $\beta$. Infected hepatocytes are lost at a rate $\delta$ per cell. Viral particles (virions) are produced at rate $p$ per infected hepatocyte and cleared at rate $c$ per virion. Chronic $\mathrm{HCV}$ infection is treated using interferon-a in combination with the antiviral drug ribavirin. Interferon-a acts primarily by blocking the production/release of new virus, although we also allow for a treatment effect in blocking de novo infection. The efficacy of treatment in blocking virion production and reducing new infections are described by two parameters, $\varepsilon_{p}$ and $\eta$, respectively. For example, a treatment efficacy in blocking virion production of $95 \%$ corresponds to $\varepsilon_{p}=0.95$.

Setting V to be proportional to I one gets the reduced system: 


$$
\begin{aligned}
& \mathrm{DT}=\mathrm{s}-\mathrm{d} \mathrm{T}-\mathrm{a} \mathrm{IT}, \\
& \mathrm{DI}=\mathrm{a} \mathrm{IT}-\mathrm{bI}\left(1-\frac{\mathrm{I}}{\mathrm{c}}\right) .
\end{aligned}
$$

Where $a, b, c, d, s$ are positive constants. There are three equilibrium points of the system (2). The first is the disease free $\left(T=\frac{s}{d}, I=0\right)$ and two endemic states $\left(\mathrm{T}_{1}, \mathrm{I}_{1}\right)$ and $\left(\mathrm{T}_{2}, \mathrm{I}_{2}\right)$ where

$$
\begin{gathered}
\mathrm{T}_{\mathrm{j}}=\mathrm{b}\left(1-\frac{\mathrm{I}}{\mathrm{c}}\right) / \mathrm{a}, \quad \mathrm{j}=1,2, \\
\mathrm{I}_{1}=\frac{c}{2}\left\{\left(1-\frac{\mathrm{d}}{\mathrm{ac}}\right)+\left[\left(1-\frac{\mathrm{d}}{\mathrm{ac}}\right)^{2}-\left(\frac{4}{\mathrm{c}}\right)\left(\frac{\mathrm{s}}{\mathrm{b}}-\frac{\mathrm{d}}{\mathrm{a}}\right)\right]^{(1 / 2)}\right\}, \\
\mathrm{I}_{2}=\frac{c}{2}\left\{\left(1-\frac{\mathrm{d}}{\mathrm{ac}}\right)-\left[\left(1-\frac{\mathrm{d}}{\mathrm{ac}}\right)^{2}-\left(\frac{4}{\mathrm{c}}\right)\left(\frac{\mathrm{s}}{\mathrm{b}}-\frac{\mathrm{d}}{\mathrm{a}}\right)\right]^{(1 / 2)}\right\} .
\end{gathered}
$$

The locally asymptotic stability condition for the disease free state is

$$
\frac{s}{d}<\frac{b}{a} .
$$

The locally asymptotic stability conditions for the two endemic states are:

$$
\begin{aligned}
& 0<I_{j}<\frac{d}{(b / c-a)}, \\
& 2\left(\frac{a s}{b}-d\right)>\left(a-\frac{d}{c}\right) I_{j}, j=1,2 .
\end{aligned}
$$

\section{The multi-strain $\mathrm{HC}$ model}

The model is given by:

$$
\begin{aligned}
& D T=s-d T-a_{1} I_{1} T-a_{2} I_{2} T, \\
& D_{1}=a_{1} I_{1} T-b_{1} I_{1}\left(1-I_{1} / c_{1}\right)+g_{1} I_{2} . \\
& D_{2}=a_{2} I_{2} T-b_{2} I_{2}\left(1-I_{2} / c_{2}\right)+g_{2} I_{1},
\end{aligned}
$$

where $a_{1}, a_{2}, b_{1}, b_{2}, c_{1}, c_{2}, d, s, g_{1}, g_{2}$ are positive constants.

There are several equilibrium solutions: The disease free state $\left(\mathrm{T}=s / d, \mathrm{I}_{1}=\mathrm{I}_{2}=0\right)$. Four one strain endemic states given by $\left(T_{1 j}, I_{1 j}, 0\right)$ and $\left(T_{2 j}, 0, I_{2 j}\right), j=1,2$ and:

$$
\begin{aligned}
& \mathrm{T}_{1 j}=\left(\mathrm{b}_{1} / \mathrm{a}_{1}\right)\left(1-\mathrm{I}_{1 j} / \mathrm{c}_{1}\right), \\
& \mathrm{I}_{11}=\left\{\left(1-\mathrm{d} / \mathrm{a}_{1} \mathrm{c}_{1}\right)+\left[\left(1-\mathrm{d} / \mathrm{a}_{1} \mathrm{c}_{1}\right)^{2}-\left(4 / \mathrm{c}_{1}\right)\left(\mathrm{s} / \mathrm{b}_{1}-\mathrm{d} / \mathrm{a}_{1}\right)\right]^{(1 / 2)}\right\} \mathrm{c}_{1} / 2, \\
& \mathrm{I}_{12}=\left\{\left(1-\mathrm{d} / \mathrm{a}_{1} \mathrm{c}_{1}\right)-\left[\left(1-\mathrm{d} / \mathrm{a}_{1} \mathrm{c}_{1}\right)^{2}-\left(4 / \mathrm{c}_{1}\right)\left(\mathrm{s} / \mathrm{b}_{1}-\mathrm{d} / \mathrm{a}_{1}\right)\right]^{(1 / 2)}\right\} \mathrm{c}_{1} / 2, \\
& \mathrm{~T}_{2 \mathrm{j}}=\left(\mathrm{b}_{2} / \mathrm{a}_{2}\right)\left(1-\mathrm{I}_{2 j} / \mathrm{c}_{2}\right), \\
& \mathrm{I}_{21}=\left\{\left(1-\mathrm{d} / \mathrm{a}_{2} \mathrm{c}_{2}\right)+\left[\left(1-\mathrm{d} / \mathrm{a}_{2} \mathrm{c}_{2}\right)^{2}-\left(4 / \mathrm{c}_{2}\right)\left(\mathrm{s} / \mathrm{b}_{2}-\mathrm{d} / \mathrm{a}_{2}\right)\right]^{(1 / 2)}\right\} \mathrm{c}_{2} / 2, \\
& \mathrm{I}_{22}=\left\{\left(1-\mathrm{d} / \mathrm{a}_{2} \mathrm{c}_{2}\right)-\left[\left(1-\mathrm{d} / \mathrm{a}_{2} \mathrm{c}_{2}\right)^{2}-\left(4 / \mathrm{c}_{2}\right)\left(\mathrm{s} / \mathrm{b}_{2}-\mathrm{d} / \mathrm{a}_{2}\right)\right]^{(1 / 2)}\right\} \mathrm{c}_{2} / 2 .
\end{aligned}
$$

The multi-strain equilibrium solutions are given by the system:

$$
\begin{aligned}
& s-d T-a_{1} I_{1} T-a_{2} I_{2} T=0, \\
& a_{1} I_{1} T-b_{1} I_{1}\left(1-I_{1} / c_{1}\right)+g_{1} I_{2}=0, \\
& a_{2} I_{2} T-b_{2} I_{2}\left(1-I_{2} / c_{2}\right)+g_{2} I_{1}=0 .
\end{aligned}
$$

The local asymptotic stability of the single healthy state is given by

$$
\begin{aligned}
& \frac{s}{d}<\frac{b_{1}}{a_{1}}, \quad \frac{s}{d}<\frac{b_{2}}{a_{2}}, \\
& \left(b_{1}-\frac{a_{1} s}{d}\right)\left(b_{2}-\frac{a_{2} s}{d}\right)>g_{1} g_{2}>0 .
\end{aligned}
$$

The local asymptotic stability of the one strain endemic states are:

$$
\mathrm{h}_{1}>0, \quad \mathrm{~h}_{3}>0, \quad \mathrm{~h}_{1} \mathrm{~h}_{2}>\mathrm{h}_{3} \text {. }
$$

For the state $\left(T_{1 j}, I_{1 j}, 0\right)$ we have:

$$
\begin{aligned}
& \mathrm{h}_{1}=d+\mathrm{b}_{1}+\mathrm{b}_{2}+\left(\mathrm{a}_{1}-2 \mathrm{~b}_{1} / \mathrm{c}_{1}\right) \mathrm{I}_{1 \mathrm{j}}-\left(\mathrm{a}_{1}+\mathrm{a}_{2}\right) \mathrm{T}_{1 \mathrm{j}}, \\
& \mathrm{h}_{2}=-\mathrm{a}_{1} \mathrm{dT}_{1 \mathrm{j}}-\mathrm{g}_{1} \mathrm{~g}_{2}+\mathrm{b}_{1}\left(1-2 \mathrm{I}_{1 \mathrm{j}} / \mathrm{c}_{1}\right)\left(\mathrm{d}+\mathrm{a}_{1} \mathrm{I}_{1 \mathrm{j}}\right)+ \\
& \left(-\mathrm{a}_{2} \mathrm{~T}_{1 \mathrm{j}}+\mathrm{b}_{2}\right)\left[\mathrm{d}-\mathrm{a}_{1} \mathrm{~T}_{1 j}+\mathrm{b}_{1}+\left(\mathrm{a}_{1}-2 \mathrm{~b}_{1} / \mathrm{c}_{1}\right) \mathrm{I}_{1 \mathrm{j}}\right]
\end{aligned}
$$

and

$$
\begin{aligned}
& h_{3}=\left(-a_{2} T_{1 j}+b_{2}\right)\left\{-a_{1} d T_{1 j}+b_{1}\left(1-2 I_{1 j} / c_{1}\right)\left(d+a_{1} I_{1 j}\right)\right\}+ \\
& g_{2}\left[-g_{1}\left(d+a_{1} I_{1 j}\right)+a_{1} a_{2} I_{1 j} T_{1 j}\right] .
\end{aligned}
$$

For the state $\left(T_{2 j}, 0, I_{2 j}\right)$ we have:

$$
\begin{aligned}
& h_{1}=d+b_{1}+b_{2}+\left(a_{2}-2 b_{2} / c_{2}\right) I_{2 j}-\left(a_{1}+a_{2}\right) T_{2 j}, \\
& h_{2}=-a_{2} d_{2 j}-g_{1} g_{2}+b_{2}\left(1-2 I_{2 j} / c_{2}\right)\left(d+a_{2} I_{2 j}\right)+ \\
& \left(-a_{1} T_{2 j}+b_{1}\right)\left[d-a_{2} T_{2 j}+b_{2}+\left(a_{2}-2 b_{2} / c_{2}\right) I_{2 j}\right],
\end{aligned}
$$

and

$$
\begin{aligned}
& \mathrm{h}_{3}=\left(-\mathrm{a}_{1} \mathrm{~T}_{2 \mathrm{j}}+\mathrm{b}_{1}\right)\left\{-\mathrm{a}_{2} \mathrm{dT}_{2 \mathrm{j}}+\mathrm{b}_{2}\left(1-2 \mathrm{I}_{2 \mathrm{j}} / \mathrm{c}_{2}\right)\left(\mathrm{d}+\mathrm{a}_{2} \mathrm{I}_{2 \mathrm{j}}\right)\right\}+ \\
& \mathrm{g}_{1}\left[-\mathrm{g}_{2}\left(\mathrm{~d}+\mathrm{a}_{2} \mathrm{I}_{2 \mathrm{j}}\right)+\mathrm{a}_{1} \mathrm{a}_{2} \mathrm{I}_{2 \mathrm{j}} \mathrm{T}_{2 \mathrm{j}}\right] .
\end{aligned}
$$

\section{We have the following conclusions:}

i) Mathematical models, when done by a group of mathematicians and $\mathrm{HCV}$ specialists give relevant results [5].

ii) The term added in equation (1) represents the well known high and low zone tolerance of the immune response (There is no Ir if the antigen number is either too high or too low [2]) since it vanishes for both limits $I \rightarrow 0$ and $\mathrm{I} \rightarrow c_{2}$. Immune response is significant for long time virus dynamics.

iii) Since multi-drugs are strongly recommended to avoid drug resistance it is proposed that a further drug should be used in addition to Peg-IFN and RBV. Notice that RBV may not be considered as 
independent drug since, when used alone, it has no effect on HCV.

iv Multi-strain phenomena is quite important. It exists in many diseases e.g. Flu, HCV Tb etc... It may cause the failure of treatment and/or vaccination protocols.

\section{Acknowledgements}

We thank Prof. A. S. Perelson for sending us copies of his work.

\section{Author details}

'Mathematics Department, Faculty of Science, Mansoura University, 35516, Mansoura, Egypt. ${ }^{2}$ Mathematics Department, Damietta Faculty of Science, Mansoura University, 34517, New Damietta, Egypt.

\section{Authors' contributions}

The two authors contributed equally to this article. All authors read and approved the final manuscript.

\section{Competing interests}

The authors declare that they have no competing interests.

Received: 11 June 2011 Accepted: 3 August 2011

Published: 3 August 2011

\section{References}

1. [http://en.wikipedia.org/wiki/Hepatitis_C].

2. Ahmed $\mathrm{E}$, Hashish AH: On modelling the immune system as a complex system. Theory in Biosciences 2006, 124(2/3):413-418.

3. Brunetto M, Colombatto P, Bonino F: Bio-mathematical models of viral dynamics to tailor antiviral therapy in chronic viral hepatitis. World J Gastroenterol 2009, 15:531-537.

4. Dahari H, Lo A, Ribeiro RM, Perelson AS: Modeling hepatitis C virus dynamics: Liver regeneration and critical drug efficacy. J Theoret Biol 2007, 247:371-381.

5. Dahari H, Shudo E, Ribeiro RM, Perelson AS: Mathematical modeling of HCV infection and treatment. In Hepatitis C methods and Protocols. 2 edition. Edited by: Tang H. Humana Press, NJ: 2008:439-453.

6. Dixit N, Layden-Almer J, Layden T, Perelson AS: Modeling how ribavirin improves interferon response rates in hepatitis C virus infection. Nature 2004, 432:922-924.

7. Chan J, Holmes A, Rabadan R: Network analysis of global influenza spread PLOS. Comp Biol 2010, 6(11):1.

\section{doi:10.1186/1753-4631-5-6}

Cite this article as: Ahmed and El-Saka: On multi-strain model for Hepatitis C. Nonlinear Biomedical Physics 2011 5:6.

\section{Submit your next manuscript to BioMed Central} and take full advantage of:

- Convenient online submission

- Thorough peer review

- No space constraints or color figure charges

- Immediate publication on acceptance

- Inclusion in PubMed, CAS, Scopus and Google Scholar

- Research which is freely available for redistribution

Submit your manuscript at www.biomedcentral.com/submit
C Biomed Central 